\title{
ANALISIS PELAKSANAAN SELF ASSESSMENT SYSTEM DAN KEPATUHAN WAJIB PAJAK BADAN DALAM RANGKA MENINGKATKAN PENERIMAAN PAJAK PADA KANTOR PELAYANAN PAJAK BEKASI BARAT
}

\author{
Fadlun Nisa ${ }^{1)}$ \\ Program Studi Akuntansi, Fakultas Ekonomi Universitas Krisnadwipayana \\ Kampus Unkris Jatiwaringin \\ Email : fadlunnisa@gmail.com \\ Siti Nurlatifah ${ }^{2)}$ \\ Program Studi Akuntansi, Fakultas Ekonomi Universitas Krisnadwipayana \\ Kampus Unkris Jatiwaringin \\ Email : ifa.latifah.unkris915@gmail.com
}

\begin{abstract}
During the last three years, namely in 2015 until 2017 the government revenue from the tax sector in West Bekasi KPP Pratama did not reach the target, the tax target that has been determined annually is not achieved, even though all efforts have been made to reach the target predetermined tax. But the obstacles encountered were also not small, including decreasing taxpayer compliance and the weakening of the economy in Indonesia. The level of implementation of the Self Assessment System and Compliance of Corporate Taxpayers at KPP Pratama Bekasi Barat can be said to be less effective and less compliant, this is because there are still many Corporate Taxpayers who are less concerned about taxes. It is shown from the number of effective corporate taxpayers which decreases annually, besides that there are still many corporate taxpayers who do not understand how to fill SPT properly, correctly, completely and do not know about the applicable tax rates, still there are also many corporate taxpayers who do not update about taxes so there are still many taxpayers who do not know about the deadline for payment, delivery, and tax reporting. All of this indicates that the corporate taxpayer's compliance in KPP Pratama Bekasi Barat declined. Of course this has an effect on tax revenue at KPP Pratama Bekasi Barat.
\end{abstract}

Keywords : Self Assesment System, Compliance of Corporate Taxpayers, Tax Revenue

\section{PENDAHULUAN}

Pemerintah memenuhi kebutuhan dana dengan mengandalkan dua sumber pokok, yaitu sumber dana luar negeri dan sumber dana dalam negeri. Sumber dana luar negeri misalnya pinjaman luar negeri seperti hibah (grant), sedangkan sumber dana dalam negeri misalnya seperti penjualan migas dan non migas serta pajak. Untuk menjadi bangsa yang mandiri, pemerintah terus mengoptimalkan sumber dana dalam negeri yang terbesar.

Selama tiga tahun terakhir, yaitu tahun 2015 hingga tahun 2017 penerimaan pemerintah dari sektor pajak di KPP Pratama Bekasi Barat tidak mencapai target sebagaimana disajikan dalam tabel -1, Target pajak yang telah ditentukan setiap tahunnya tidak tercapai, padahal segala upaya sudah dilakukan untuk mencapai target pajak yang telah ditentukan.
Namun hambatan yang ditemui juga tidak sedikit, antara lain menurunnya kepatuhan Wajib Pajak dan melemahnya perekonomian di Indonesia juga ikut berperan.

Tabel -1

Data Realisasi Penerimaan PPh Badan

\begin{tabular}{|c|c|c|c|}
\hline Tahun & $\begin{array}{c}\text { Target } \\
(\mathbf{1})\end{array}$ & $\begin{array}{c}\text { Total realisasi } \\
(\mathbf{2})\end{array}$ & $\begin{array}{c}\boldsymbol{\%} \\
(\mathbf{3})=(\mathbf{2}: \mathbf{1})\end{array}$ \\
\hline 2015 & 1.151 .336 .284 .000 & 931.738 .698 .773 & $1,23 \%$ \\
\hline 2016 & 1.357 .185 .002 .000 & 854.000 .966 .085 & $1,58 \%$ \\
\hline 2017 & 1.169 .435 .499 .000 & 1.028 .995 .535 .806 & $1,13 \%$ \\
\hline \multicolumn{3}{|l}{ Sumber: Pengolahan Data \& Informasi KPP Pratama Bekasi Barat (2018) } \\
\hline
\end{tabular}

Penerimaan dari sektor pajak diharapkan mampu mengurangi ketergantungan pada utang luar negeri serta mampu membangkitkan kembali kepercayaan diri bangsa Indonesia. Hal ini memiliki tanggung jawab kesadaran yang tinggi bagi wajib pajak maupun 
Printed ISSN 2406-7415

e-ISSN 2655-9919

Jurnal Akuntansi \& Bisnis Krisnadwipayana

Vol. 6 No. 2 (Mei - Agustus) 2019

petugas pajak (fiskus) dengan pengertian pajak berdasarkan pasal 1 UU tentang ketentuan Umum dan Tata Cara perpajakan (KUP) No. 6 Tahun 1983 jo UU KUP No. 16 Tahun 2009, bahwa pajak merupakan kontribusi wajib kepada negara yang terutang oleh orang pribadi atau badan yang bersifat memaksa berdasarkan ketentuan undangundang, dengan tidak mendapatkan imbalan secara langsung dan digunakan untuk keperluan negara bagi sebesar besarnya kemakmuran rakyat.

Upaya mewujudkan kepatuhan wajib pajak melalui Self Assessment System pada kenyataannya belum menghasilkan semua potensi pajak yang ada dapat digali. Sebab masih banyak Wajib Pajak yang belum memiliki kesadaran akan betapa pentingnya pemenuhan kewajiban perpajakan, baik bagi mereka sendiri maupun sebagai warga negara yang baik. Dalam kondisi tersebut keberadaan Self Assessment System masih memungkinkan wajib pajak untuk melakukan kecurangan pajak. Tanpa adanya penelitian dan pemeriksaan pajak serta tidak adanya ketegasan dari instansi pajak, maka ketidakpatuhan wajib pajak tersebut dapat berkembang sedemikian rupa sehingga bisa mencapai suatu tingkat dimana sistem perpajakan menjadi stagnan.

Kepatuhan Wajib Pajak Badan di Kantor Pelayanan Pajak Pratama Bekasi Barat dari tahun 2015 sampai dengan tahun 2017 masih sangat fluktuatif. Ini berdasarkan data yang ada, sebagaimana tabel-2 berikut :

Tabel -2

Kepatuhan Wajib Pajak Badan di Kantor Pelayanan Pajak Pratama Bekasi Barat

\begin{tabular}{|c|c|c|c|c|}
\hline Tahun & $\begin{array}{c}\text { Wajib Pajak } \\
\text { Terdaftar (PKP \& } \\
\text { NON PKP) } \\
\text { (1) }\end{array}$ & $\begin{array}{c}\text { Wajib Pajak } \\
\text { Badan Wajib } \\
\text { SPT } \\
\text { (2) }\end{array}$ & $\begin{array}{c}\text { Realisasi } \\
\text { Penyampaian SPT } \\
\text { Oleh WP Efektif } \\
\text { (3) }\end{array}$ & $\begin{array}{c}\text { Rasio } \\
\text { Kepatuhan } \\
(4)=(3: 2)\end{array}$ \\
\hline 2015 & 7.567 & 3.588 & 1.651 & $45,4 \%$ \\
\hline 2016 & 8.205 & 3.630 & 1.309 & $39,5 \%$ \\
\hline 2017 & 8.870 & 3.313 & 1.206 & $36,40 \%$ \\
\hline
\end{tabular}

Dari data diatas dapat dilihat bahwa Wajib Pajak Badan meliputi Pengusaha Kena Pajak (PKP) dan Non PKP yang terdaftar di KPP Pratama Bekasi Barat dari tahun 2015 sampai
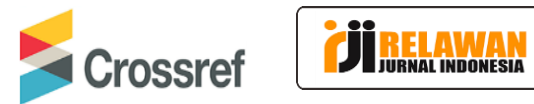

dengan tahun 2017 terus mengalami kenaikan. Rasio kepatuhan antara realisasi penyampaian Surat Pemberitahuan (SPT) dan Wajib Pajak efektif (yang terdaftar dan wajib menyampaikan SPT di KPP Pratama Bekasi Barat) juga mengalami penurunan. Hal ini disebabkan masih banyaknya Wajib Pajak Badan yang belum memenuhi kewajiban perpajakannya terkait dengan ketidaktahuan Wajib Pajak Badan dalam pengisian SPT, dan masih banyak pula Wajib Pajak Badan yang tidak mengetahui batas akhir pembayaran maupun penyampaian dan pelaporan SPT. Hal inilah yang menyebabkan kepatuhan Wajib Pajak Badan jadi menurun. Menurutnya kepatuhan Wajib Pajak Badan di KPP Pratama Bekasi Barat berpengaruh terhadap penerimaan pajak. Dampaknya adalah menurunnya penerimaan pajak di KPP Pratama Bekasi Barat, dan tidak tercapainya target penerimaan yang telah ditentukan oleh pihak KPP Pratama Bekasi Barat, sebagaimana tabel -1 yang telah disajikan diatas.

Untuk menjaga agar wajib pajak tetap pada koridor peraturan perpajakan yang telah ditetapkan dan agar penerimaan pajak meningkat selain dilihat dari tingkat kepatuhan wajib pajak badannya, mungkin ada faktor lain yang juga berpengaruh terhadap hubungan antara kepatuhan wajib pajak badan dan peningkatan penerimaan pajak.

Menurut Pusat Data Informasi (PDI) KPP Pratama Bekasi Barat, bahwa pemahaman terhadap Self Assessment System mampu menerangkan perubahan yang terjadi kepada tingkat kepatuhan Wajib Pajak Badan mempunyai indikator sebagai tolak ukur yaitu menghitung pajak sesuai dengan ketentuan yang berlaku, memperhitungkan pajak dengan benar, membayar pajak sesuai dengan ketentuan yang berlaku dan ketepatan pelaporan SPT, mengisi SPT sesuai dengan ketentuan yang berlaku, ketetapan dalam perhitungan dan pembayaran pajak, income yang dilaporkan sesuai dengan ketentuan yang berlaku. Selain itu peningkatan penerimaan pajak menurut PDI adalah ketetapan dalam membayar pajak, membayar tarif pajak sesuai dengan ketentuan yang berlaku. Indikator tersebut sudah digunakan oleh para peneliti terdahulu. Menurut para peneliti terdahulu 
Printed ISSN 2406-7415

e-ISSN 2655-9919

Jurnal Akuntansi \& Bisnis Krisnadwipayana

Vol. 6 No. 2 (Mei - Agustus) 2019

menggunakan indikator tersebut karena faktorfaktor yang sudah disebutkan diatas mempengaruhi tingkat kepatuhan Wajib Pajak Badan dan peningkatan penerimaan pajak.

\section{TINJAUAN PUSTAKA \\ Definisi Pajak}

Pengertian pajak berdasarkan Pasal $1 \mathrm{UU}$ tentang Ketentuan Umum dan Tata Cara Perpajakan (KUP) No. 6 Tahun 1983 jo UU KUP No. 16 Tahun 2009:

"Pajak adalah kontribusi wajib kepada negara yang terutang oleh orang pribadi atau badan yang bersifat memaksa berdasarkan ketentuan Undang-Undang, dengan tidak mendapatkan imbalan secara langsung dan digunakan untuk keperluan negara bagi sebesar-besarnya kemakmuran rakyat"

Pengertian pajak menurut (Soemitro \& Sugiharti, 2010,hal 8) :

Pajak merupakan peralihan kekayaan dari rakyat kepada pemerintah yang tidak ada imbalannya yang secara langsung dapat ditunjuk. Peralihan kekayaan seperti itu hanya dapat berupa penggarongan, perampasan, pencopetan, (dengan paksa), atau pemberian hadiah dengan sukarela dan ikhlas (tanpa paksaan).

\section{Sistem Perpajakan}

Menurut Waluyo (2011) Indonesia mempunyai beberapa sistem pemungutan pajak yaitu :

1. Official Assessment System, merupakan sistem pemungutan pajak yang memberi wewenang kepada pemerintah fiskus untuk menentukan besarnya pajak terutang

2. Self Assessment System, merupakan sistem perpajakan yang memberikan wewenang, kepercayaan, tanggung jawab, kepada wajib pajak untuk menghitung, memperhitungkan, membayarkan dan melaporkan sendiri besarnya pajak yang harus dibayar

3. Withholding System, merupakan sistem pemungutan pajak yang memeberikan wewenang kepada pihak ketiga untuk memotong atau memungut besarnya pajak yang terutang oleh wajib pajak.

\section{Self Assessment System}

Sistem Self Assessment yang diterapkan di Indonesia sejak tahun 1983 memberikan wajib

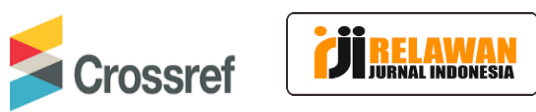

pajak kesempatan untuk menentukan sendiri jumlah pajak yang terutang setiap tahunnya sesuai dengan ketentuan perundang-undangan perpajakan yang berlaku. Sistem administrasi pajak yang modern mengoptimalkan pemungutan pajak dengan cara meminimalkan biaya administrasi dan biaya kepatuhan wajib pajak. Pengalaman menunjukkan bahwa kepatuhan sukarela dapat dicapai dengan sangat baik melalui penerapan prinsip-prinsip Self Assessment. Akan tetapi, banyak otoritas pajak telah menerapkan prinsip-prinsip tersebut di dalam undang-undang Pajak Penghasilan ( $\mathrm{PPh})$ mereka, sedangkan implementasinya tidak konsisten. Otoritas pajak tetap mengacu pada pemeriksaan pajak yang mereka lakukan, untuk mendapat target penerimaan pajak. Hal ini juga berlaku di Indonesia."

Sistem Self Assessment terlihat dari mekanisme pelaporan penghasilan ke dalam Surat Pemberitahuan Pajak tahunan (SPT). Penghasilan yang diterima/diperoleh dalam setahun dilaporkan oleh Wajib Pajak ke dalam SPT. Ada dua jenis SPT PPh sesuai dengan jenis Wajib Pajak, yaitu SPT tahun PPh orang pribadi dan SPT tahunan badan.

Sistem Self Assessment diterapkan dengan cara wajib pajak sendiri yang menghitung, menetapkan, menyetorkan, dan melaporkan pajak yang terutang. Fiskus hanya berperan untuk mengawasi, misalnya memeriksa apakah Surat Pemberitahuan (SPT) telah diisi dengan lengkap dan semua lampiran sudah disertakan, meneliti kebenaran perhitungan dan penulisan. Indikator Self Assessment System yaitu:

1. Menghitung

2. Memperhitungkan

3. Membayar, dan

4. Melapor

\section{Kepatuhan Wajib Pajak}

Dalam Undang-undang Nomor 28 Tahun 2007 tentang ketentuan Umum dan Tata Cara Perpajakan Pasal 1 ayat 2 disebutkan pengertian Wajib Pajak yaitu :

Wajib Pajak merupakan Orang Pribadi atau Badan yang mempunyai hak dan kewajiban, meliputi pembayar pajak, pemungut pajak, pemotong pajak, yang diatur dalam perundang- 
Printed ISSN 2406-7415

e-ISSN 2655-9919

Jurnal Akuntansi \& Bisnis Krisnadwipayana

Vol. 6 No. 2 (Mei - Agustus) 2019

undangan perpajakan. Wajib pajak bukan hanya bagi orang yang sudah memiliki (NPWP) saja, namun juga bagi yang sudah memenuhi persyaratan sebagai wajib pajak meskipun belum memiliki NPWP.

Berdasarkan keputusan Menteri Keuangan No.554/K.M.K04/2000 dalam Sony Devano dan Siti Kurnia Rahayu (2010:112), menyatakan bahwa:

"Kepatuhan perpajakan adalah tindakan wajib pajak dalam pemenuhan kewajiban perpajakannya sesuai dengan ketentuan peraturan perundang-undangan dan peraturan pelaksanaan perpajakan yang berlaku dalam suatu negara"

Menurut Gunadi (2013:94) pengertian kepatuhan wajib pajak adalah:

"Dalam hal ini diartikan bahwa wajib pajak mempunyai kesediaan untuk memenuhi kewajiban perpajakannya sesuai dengan aturan yang berlaku tanpa perlu diadakan pemeriksaan, investigasi seksama, peringatan ataupun ancaman dan penerapan sanksi baik hukum maupun administrasi”.

\section{Jenis-jenis Kepatuhan}

Adapun jenis-jenis kepatuhan wajib pajak menurut Siti Kurnia Rahayu (2010:138) yaitu:

1. Kepatuhan formal adalah suatu keadaan dimana wajib pajak memenuhi kewajiban secara formal sesuai dengan ketentuan dalam undang-undang perpajakan. Misalnya menyampaikan Surat Pemberitahuan (SPT) $\mathrm{PPh}$ tersebut sudah benar atau belum. Yang terpenting Surat Pemberitahuan (SPT) $\mathrm{PPh}$ Badan sudah disampaikan sebelum tanggal 30 April.

2. Kepatuhan material adalah suatu keadaan dimana wajib pajak secara substantif/hakikatnya memenuhi semua ketentuan material perpajakan yaitu sesuai isi dan jiwa undang-undang pajak kepatuhan material juga dapat meliputi kepatuhan formal. Disini wajib pajak yang bersangkutan, selain memperhatikan kebenaran yang sesungguhnya dari isi Surat Pemberitahuan (SPT) PPh tersebut.

\section{Kriteria Kepatuhan Wajib Pajak}

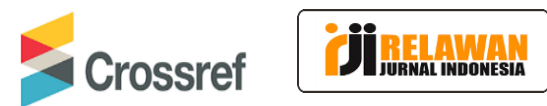

Berdasarkan peraturan Menteri Keuangan Nomor: 74/PMK.03/2012, bahwa kriteria kepatuhan Wajib Pajak adalah:

1. Tepat waktu dalam menyampaikan SPT

2. Tidak mempunyai tunggakan pajak untuk semua jenis pajak, kecuali telah memperoleh izin untuk mengangsur atau menunda pembayaran pajak.

3. Laporan keuangan diaudit oleh Akuntan Publik atau lembaga pengawasan keuangan pemerintah dengan pendapat wajar tanpa pengecualian selama 3 tahun berturut-turut.

4. Tidak pernah dikenakan pidana karena melakukan tindak pidana dibidang perpajakan berdasarkan putusan pengadilan yang telah mempunyai kekuatan hukum tetap dalam jangka waktu 5 tahun terakhir.

\section{Indikator kepatuhan Wajib Pajak}

Dengan sistem Self Assessment, indikator kepatuhan Wajib Pajak bersedia melaporkan SPT dan melaporkan semua penghasilannya secara akurat. Dengan sistem itu pula diharapkan Wajib Pajak dapat patuh secara sukarela (Voluntary compliance level-VCL). VCL adalah perbandingan antara pajak yang sesungguhnya dilaporkan dengan pajak yang seharusnya dilaporkan dengan pajak yang seharusnya dilaporkan.

Dengan UU KUP, indikator kepatuhan Wajib Pajak dapat dilihat dari:

1. Aspek kepatuham waktu pelaporan SPT

2. Aspek Income yang dilaporkan sesuai dengan kepatuhan yang berlaku

3. Tagihan pajak (STP/SKP) dibayar sebelum jatuh tempo.

4. Ketetapan dalam perhitungan dan pembayaran pajak terutang.

\section{Wajib Pajak Badan}

Menurut Undang-Undang Nomor 28 tahun 2007 tentang Ketentuan Umum dan Tata Cara Perpajakan, Pasal 1 ayat (3):

"Badan adalah sekumpulan orang atau modal yang merupakan kesatuan, baik yang melakukan usaha maupun yang tidak melakukan usaha".

Wajib pajak Badan adalah Badan yang dimaksud seperti yang dimaksud pada UU KUP, meliputi pembayaran pajak, pemotongan pajak, dan pemungut pajak yang mempunyai hak dan 
Printed ISSN 2406-7415

e-ISSN 2655-9919

Jurnal Akuntansi \& Bisnis Krisnadwipayana

Vol. 6 No. 2 (Mei - Agustus) 2019

kewajiban perpajakan sesuai dengan ketentuan peraturan perundang-undangan perpajakan atau memiliki kewajiban objektif serta telah mendaftarkan diri untuk memperoleh Nomor Pokok Wajib Pajak (NPWP).

Wajib Pajak Badan terdiri dari:

1. Badan milik pemerintah (BUMN, dan BUUMD)

2. Badan milik Swasta (PT,CV, Koperasi, Lembaga, dan Yayasan)

\section{Subjek Wajib Pajak Badan}

Subjek pajak Badan dibedakan menjadi 2 bagian yaitu:

1. Subjek pajak dalam Negeri

Badan yang didirikan atau bertempat kedudukan di Indonesia. Unit tertentu dari badan pemerintah yang memenuhi kriteria:

a. Pembentuknya berdasarkan ketentuan peraturan perundang-undangan

b. Pembiayaannya bersumber dari APBN atau APBD

c. Penerimaannya dimasukan dalam APBN atau APBD

d. Pembukuannya diperiksa oleh aparat pengawasan fungsional Negara

2. Subjek Pajak Luar Negeri

a. Badan yang tidak didirikan dan tidak bertempat kedudukan di Indonesia, yang menjalankan usaha atau melakukan kegiatan melalui BUT di Indonesia.

b. Badan yang tidak didirikan dan tidak bertempat kedudukan di Indonesia, yang dapat menerima atau memperoleh penghasilan dari Indonesia tidak dari menjalankan usaha atau melakukan kegiatan melalui BUT di Indonesia.

\section{Tarif Pajak Badan}

Badan ketentuan yang mengatur undang-undang tarif pajak adalah UndangUndang Republik Indonesia Nomor 7 tahun 1983 tentang Pajak Penghasilan yang telah diubah dengan Undang-Undang Repubilik Indonesia Nomor 36 Tahun 2008 tentang pajak penghasilan (Ikatan Akuntan Indonesia, 2013:138) mengenai tarif pajak Badan adalah:

1. Pada 17 ayat (1) huruf $b$ :

Tarif PPh Badan menganut tarif tunggal yaitu, sebesar $28 \%$. tarif ini berlaku pada tahun 2009 kemudian diturunkan menjadi $25 \%$ pada tahun 2010. Tarif PPh Badan sebesar $25 \%$ efektif berlaku untuk tahun 2010 dan seterusnya. Tarif ini ditetapkan untuk Wajib Pajak Badan dalam negeri dan bentuk usaha tetap (BUT).

2. Pasal 17 ayat 2 (b) :

Tarif ini diterapkan pada wajib pajak badan dalam negeri yang berbentuk perseroan terbuka yang memperoleh pengurngan tarif sebesar 5\% lebih rendah dan tarif normal.

3. Tarif PPh Wajib Pajak Tertentu

Wajib Pajak Badan dalam negeri dengan peredaran bruto sampai dengan Rp. 50.000.000.000,00 mendapat fasilitas berupa pengurangan tarif sebesar $50 \%$ dari tarif yang sebagaimana dimaksud dalam pasal 17 ayat (1) huruf b dan ayat (2a) yang dikenakan atas Pengusaha Kena Pajak dari bagian peredaran bruto sampai dengan $\mathrm{Rp}$ 4.800.000.000,00.

\section{Tabel -3}

Tarif Pajak Penghasilan untuk Badan

\begin{tabular}{|c|c|}
\hline $\begin{array}{c}\text { Penghasilan Kotor } \\
\text { (Peredaran Bruto) }\end{array}$ & Tarif Pajak \\
\hline Lebih dari Rp. 50.000.000.000,00 & $25 \% \times$ PKP \\
\hline Lebih dari Rp. 4.800.000.000,00 & $\begin{array}{c}\{0,25-(0,6 \text { Milyar/Penghasilan kotor) }) \times \\
\text { PKP }\end{array}$ \\
\hline Kurang dari Rp. 4.800.000.000,00 & $\begin{array}{c}1 \% \times \text { Penghasilan Kotor (Peredaran } \\
\text { Bruto) }\end{array}$ \\
\hline
\end{tabular}

\section{Jenis-jenis Sanksi Perpajakan}

Dalam ketentuan perpajakan, ada dua macam sanksi pajak, yaitu: Sanksi Administrasi dan Sanksi Pidana. Perbedaan dari kedua sanksi tersebut ialah bahwa sanksi pidana berakibat pada hukuman badan seperti penjara atau kurungan. Pengenaan sanksi pidana dikenakan terhadap siapapun yang melakukan tindak pidana dibidang perpajakan. Sedangkan sanksi Administrasi berupa denda (dalam UU Ketentuan Umum dan Tata Cara Perpajakan disebut sebagai Bunga, denda, atau kenaikan).

Apabila Surat Pemberitahuan (SPT) tidak disampaikan oleh Wajib Pajak Badan dalam jangka waktu atau batas waktu perpanjangan yang sudah diberikan, maka Wajib Pajak Badan akan dikenakan sanksi denda sebesar:

a) Rp. 500.000,00 untuk SPT Masa PPN

b) Rp. 100.000,00 untuk denda lapor (PPh 21, 
Printed ISSN 2406-7415

e-ISSN 2655-9919

Jurnal Akuntansi \& Bisnis Krisnadwipayana

Vol. 6 No. 2 (Mei - Agustus) 2019

PPh 23, Pasal 4 (2), dan PPh 25 atau SPT Masa lainnya.

c) Rp. 1.000.000,00 untuk SPT Tahunan Pajak Penghasilan Wajib Pajak Badan.

Sumber Penerimaan Pajak

1. Pajak penghasilan $(\mathrm{PPh})$

Menurut Undang-Undang Nomor 17 Tahun 2000 pajak penghasilan adalah setiap tambahan kemampuan ekonomis yang diterima atau diperoleh wajib pajak. Baik yang berasal dari Indonesia maupun dari luar Indonesia, yang dapat dipakai untuk konsumsi atau untuk memenuhi kekayaan wajib pajak yang bersangkutan dengan nama dan dalam bentuk apapun. pajak penghasilan juga merupakan pungutan resmi oleh pemerintah yang ditunjukan kepada masyarakat yang berpenghasilan untuk membiayai pengeluaran-pengeluaran pemerintah.

2. Pajak Pertambahan Nilai (PPN)

Berdasarkan Undang-Undang Nomor 42 Tahun 2009 PPN adalah pajak yang dikenakan atas Konsumsi Barang Kena Pajak atau Jasa Kena Pajak di dalam daerah pabean (dalam wilayah Indonesia). orang Pribadi, perusahaan, maupun pemerintah yang mengkonsumsi Barang Kena Pajak atau Jasa Kena Pajak, kecuali ditentukan lain oleh Undang-Undang PPN.

3. Pajak Penjualan atas Barang Mewah (PPnBM)

Selain dikenakan PPN atas pengkonsumsian Barang Kena Pajak tertentu yang tergolong mewah juga dikenakan PPnBM. Menurut Undang-Undang Nomor 42 Tahun 2009 yang dimaksud dengan Barang Kena Pajak yang tergolong mewah adalah:
a. Barang yang merupakan bukan kebutuhan pokok
b. Barang yang dikonsumsi oleh masyarakat tertentu; atau
c. Pada umumnya barang yang biasa dikonsumsi oleh masyarakat berpenghasilan tinggi; atau
d. Barang tersebut dikonsumsi untuk menunjukan status; atau
e. Apabila dikonsumsi dapat merusak kesehatan dan moral masyarakat, serta

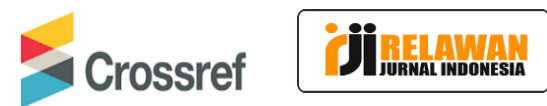

4. Bea Materai

mengganggu ketertiban masyarakat.

Bea Materai dikenakan atas dokumendokumen sebagai berikut:

a. Surat berharga yang dengan nominal lebih dari Rp. 1.000.000,00.

b. Efek dengan nama dalam bentuk apapun sepanjang harga nominal lebih dari Rp. 1.000.000,00

c. Dokumen yang digunakan sebagai alat pembuktian didepan pengadilan

d. Surat perjanjian atau surat lain yang dibuat untuk alat pembuktian mengenai perbuatan, kenyataan, atau keadaan yang bersifat perdata.

e. Akta-akta notaris beserta salinannya.

f. Akta-akta yang dibuat Pejabat Pembuat Akta Tanah (PPAT) berikut salinannya.

\section{Indikator Peningkatan Penerimaan Pajak}

Adapun indikator dalam meningkatkan

Penerimaan pajak ialah sebgai berikut:

1. Ketetapan dalam membayar pajak.

2. Tarif pajak sesuai dengan ketentuan yang berlaku

\section{METODE PENELITIAN}

Sumber data dalam penelitian ini adalah data Primer dan data Sekunder. Data primer adalah data yang diperoleh secara langsung dari objek peneliti. Data Deskriptif diperoleh langsung dengan cara menemui subyek penelitian dengan wawancara langsung kepada Key Informan, dan jenis penelitian Deskriptif adalah mengemukakan bahwa ditinjau dari jenis masalah yang diselidiki, teknik dan alat yang digunakan, serta tempat dan waktu.

Populasi dalam penelitian ini adalah Perusahaan yang terdaftar di KPP Pratama Bekasi Barat, dengan jumlah 4.777 Wajib Pajak Badan. Sedangkan dalam menentukan jumlah sampel, penulis mendapatkan tingkat kesalahan sebesar $10 \%$ karena dalam penelitian tidak mungkin hasilnya sempurna $100 \%$. Maka makin besar tingkat kesalahan maka semakin sedikit ukuran sampel. Jumlah sampel yang digunakan adalah 97. berdasarkan hasil perhitungan dengan menggunakan rumus slovin didapatkan dengan jumlah 97sampel. 
Printed ISSN 2406-7415

e-ISSN 2655-9919

Jurnal Akuntansi \& Bisnis Krisnadwipayana

Vol. 6 No. 2 (Mei - Agustus) 2019

\section{HASIL DAN PEMBAHASAN}

Penelitian ini dilakukan terhadap Wajib Pajak Badan Efektif yang terdaftar di Kantor Pelayanan Pajak (KPP) Pratama Bekasi Barat. Wajib Pajak Badan efektif yang terdaftar di kantor Pelayanan Pajak (KPP) Pratama Bekasi Barat sebagian besar ikut berpartisipasi pengisian kuesioner dalam penelitian ini.

Pengumpulan data dilakukan dengan pengisian kuesioner di Kantor Pelayanan Pajak (KPP) Pratama Bekasi Barat dengan Objek penelitian Wajib Pajak Badan yang efektif yang telah terdaftar di Kantor Pelayanan Pajak (KPP) Pratama Bekasi Barat.

\section{Deskriptif Responden}

Berdasarkan data yang terkumpul, responden dalam penelitian adalah Wajib Pajak Badan. Dalam penelitian ini di deskripsikan dengan berdasarkan pernyataan yang tertera pada kuesioner yaitu terdiri dari: Jenis kelamin. Usia, dan Pendidikan terakhir.

A. Deskripsi Responden berdasarkan jenis kelamin

Tabel -4

Jenis Kelamin Responden

\begin{tabular}{|c|c|c|}
\hline Jenis Kelamin & Jumlah & Persentase $(\%)$ \\
\hline Lakil-aki & 71 & $73 \%$ \\
\hline peremplan & 26 & $26 \%$ \\
\hline Total & 97 & $100 \%$ \\
\hline
\end{tabular}

Jumlah data responden sesuai dengan jenis kelamin diatas, jumlah responden yang berjenis kelamin laki-laki berjumlah 71 responden atau dengan persentase sebesar $73 \%$ dan sedangkan responden berjenis kelamin perempuan berjumlah 26 responden atau dengan persentase $26 \%$

B. Deksripsi Responden berdasarkan Usia

Tabel -5

Usia Responden

\begin{tabular}{|c|c|c|}
\hline Usia & Jumalah & Persentase \\
\hline$<25$ Tahun & 19 & $19 \%$ \\
\hline 26-35 Tahun & 41 & $42 \%$ \\
\hline$>36$ Tahun & 37 & $38 \%$ \\
\hline Total & 97 & $100 \%$ \\
\hline Sumber: data diolah penulis (2018)
\end{tabular}

Jumlah data responden sesuai dengan usia diatas, jumah responden dengan usia $<25$ Tahun berjumlah 19 responden atau dengan persentase $19 \%$, jumalah responden berusia 26-35 tahun berjumlah 41 respondenatau dengan peresentase $42 \%$ sedangkan jumlah responden berusia $>36$ tahun berjumlah 37 responden atau sebesar 38\%.

\section{Deskripsi Responden Berdasarkan Pendidikan Terakhir}

Tabel -6

Pendidikan Terakhir Responden

\begin{tabular}{|l|c|c|}
\hline \multicolumn{1}{|c|}{ Pendidikan Terakhir } & Jumlah & Persentase (\%) \\
\hline SLTA & 40 & $41 \%$ \\
\hline D-3/Sederajat & 12 & $12 \%$ \\
\hline S-1 & 46 & $47 \%$ \\
\hline Total & 97 & $100 \%$ \\
\hline Sumber : data diolah penulis (2018)
\end{tabular}

Berdasarkan data pendidikan terakhir responden diatas, bahwa jumlah responden dengan tingkat pendidikan terakhir SLTA yaitu sebanyak 40 orang atau sekitar $41 \%, \mathrm{D}-3$ sederajat sebanyak 12 orang atau sekitar $12 \%$, dan S-1 sebanyak 46 orang atau sekitar $47 \%$. Adapun uraian dari rekapitulasi jawaban responden diatas dapat dilihat pada uraian berikut ini, yaitu:

\section{Variabel Self Assessment System}

Variabel Self Assessment System diukur melalui 4 indikator antara lain menghitung, memperhitungkan, membayar dan melaporkan. Dari keempat indikator tersebut dapat diuraikan hasil rekapitulasi jawaban berdasarkan butir pertanyaan kuesioner yang disebar pada 97 Wajib Pajak Badan yang menjadi sampel penelitian. Berikut uraian dari jawaban responden pada pertanyaan kuesioner variabel Self Assessment System (SAS) meliputi 5 pertanyaan, sebagaimana tabel-7 dapat dilihat sebagai berikut:

Tabel -7

\section{Hasil Kuesioner}


Printed ISSN 2406-7415

e-ISSN 2655-9919

Jurnal Akuntansi \& Bisnis Krisnadwipayana

Vol. 6 No. 2 (Mei - Agustus) 2019

\begin{tabular}{|c|c|c|c|c|c|c|c|}
\hline \multirow[b]{2}{*}{ Kode } & \multirow[b]{2}{*}{ Pertanyaan } & \multicolumn{2}{|c|}{ Ya } & \multicolumn{2}{|c|}{ Tidak } & \multicolumn{2}{|c|}{ Total } \\
\hline & & Jawaban & $\begin{array}{c}\text { Persentase } \\
(\%)\end{array}$ & Jawaban & $\begin{array}{c}\text { Persen } \\
\text { tase } \\
(\%)\end{array}$ & Jumlah & $\begin{array}{c}\text { Persent } \\
\text { se } \\
(\%)\end{array}$ \\
\hline SAS1 & \begin{tabular}{|l|} 
Apakah \\
Bapak/ibu/Saudara/i sudah \\
mengerti cara menghitung \\
pajak dengan benar?
\end{tabular} & 36 & $37 \%$ & 61 & $62 \%$ & 97 & $100 \%$ \\
\hline SAS2 & \begin{tabular}{|l|} 
Apakah \\
Bapak/lbu/Saudara/i \\
melakukan penyampaian \\
sendiri atas SPT? \\
\end{tabular} & 39 & $40 \%$ & 58 & $59 \%$ & 97 & $100 \%$ \\
\hline SAS3 & \begin{tabular}{|l|} 
Apakah \\
Bapak/Ibu/Saudara/i \\
melakukan pengisian \\
sendiri atas SPT? \\
\end{tabular} & 39 & $40 \%$ & 58 & $59 \%$ & 97 & $100 \%$ \\
\hline SAS4 & \begin{tabular}{|l|} 
Apakah \\
Bapak/Ibu/Saudara/i \\
melakukan pembayaran \\
tepat waktu?
\end{tabular} & 26 & $26 \%$ & 71 & $73 \%$ & 97 & $100 \%$ \\
\hline SAS5 & $\begin{array}{l}\text { Apakah } \\
\text { Bapak/Ibu/Saudara/i sudah } \\
\text { menyampaikan SPT } \\
\text { dengan benar, lengkap dan } \\
\text { jelas? }\end{array}$ & 34 & $35 \%$ & 63 & $64 \%$ & 97 & $100 \%$ \\
\hline
\end{tabular}

Variabel Kepatuhan Wajib Pajak

Variabel kepatuhan wajib pajak dikur melalui 4 indikator antara lain yaitu, Mengisi SPT sesuai dengan ketentuan yang berlaku, Ketetapan dalam menghitung, dan membayar pajaknya, Income yang berlaku sesuai dengan ketentuan yang berlaku, dan Ketetapan waktu. Dari keempat indikator tersebut dapat diuraikan hasil rekapitulasi jawaban berdasarkan masing-masing pertanyaan yang disebar pada 97 Wajib Pajak Badan yang menjadi sampel dalam penelitian ini. Berikut uraian dari jawaban responden pada pertanyaan kuesioner variabel Kepatuhan Wajib Pajak (KWP) Badan meliputi 5 pertanyaan, sebagaimana tabel -9 dapat dilihat sebagai berikut:

\section{Tabel -8}

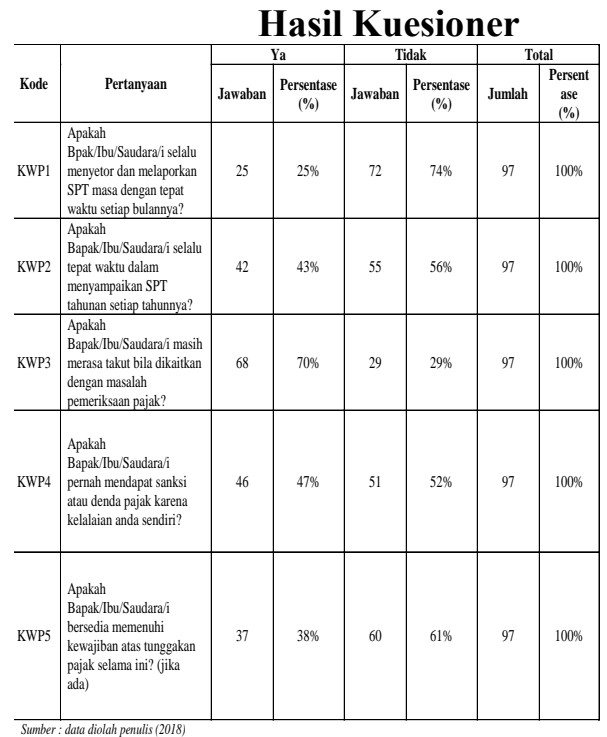

Variabel Penerimaan Pajak
Variabel Penerimaan Pajak (PP) meliputi 7 pertanyaan, sebagaimana tabel-9 diukur dengan dua indikator antara lain yaitu dengan Ketetapan membayar pajak dan Membayar pajak sesuai dengan ketentuan yang berlaku. Dari kedua indikator tersebut dapat diuraikan rekapitulasi jawaban berdasarkan masing masing pertanyaan kuesioner yang disebarkan kepada 97 Wajib Pajak Badan yang menjadi sampel dalam penelitian ini. Berikut ini adalah uraian dari jawaban responden pada pertanyaan kuesioner variabel penelitian, yaitu:

\section{Tabel -9}

\section{Hasil Kuesioner}

\begin{tabular}{|c|c|c|c|c|c|c|c|}
\hline \multirow[b]{2}{*}{ Kode } & \multirow[b]{2}{*}{ Pertanyaan } & \multicolumn{2}{|c|}{ Yas } & \multicolumn{2}{|c|}{$\begin{array}{l}\text { Tidak } \\
\text { Perseg }\end{array}$} & \multicolumn{2}{|c|}{ Total } \\
\hline & & \begin{tabular}{|l} 
Jawaban \\
\end{tabular} & $\begin{array}{l}\text { Persentase } \\
(\%)\end{array}$ & \begin{tabular}{|l} 
Jawaban \\
\end{tabular} & \begin{tabular}{|l|} 
Persentase \\
$(\%)$
\end{tabular} & Jumlah & $\begin{array}{c}\text { Persentase } \\
(\%)\end{array}$ \\
\hline PP1 & $\begin{array}{l}\text { Apakah } \\
\text { Bpak/lbu/Saudara/i } \\
\text { sudah membayar pajak } \\
\text { sesuai dengan tarif pajak } \\
\text { Badan yang berlaku? }\end{array}$ & 65 & $67 \%$ & 32 & $32 \%$ & 97 & $100 \%$ \\
\hline PP2 & $\begin{array}{l}\text { Apakah } \\
\text { Bpak/bu/Saudara/i } \\
\text { mengetahui tentang tarif } \\
\text { pajak Badan? }\end{array}$ & 81 & $83 \%$ & 16 & $16 \%$ & 97 & $100 \%$ \\
\hline PP3 & $\begin{array}{l}\text { Apakakh } \\
\text { Bpak/hu/Saudarafi } \\
\text { selalu melaporkan } \\
\text { Income sesuai dengan } \\
\text { ketentuan yang berlaku? }\end{array}$ & 23 & $23 \%$ & 74 & $76 \%$ & 97 & $100 \%$ \\
\hline PP4 & \begin{tabular}{|l|} 
Appakah \\
Bpakhlbusaudaraif \\
mengalokasikan \\
dananya untuk \\
membayar pajak? \\
\end{tabular} & 12 & $12 \%$ & 85 & $87 \%$ & 97 & $100 \%$ \\
\hline PP5 & $\begin{array}{l}\text { Apakah } \\
\text { Bpak//lbu/Saudara/i } \\
\text { melakukan pembukuan? } \\
\text { (jika dana omset usaha } \\
4.800 .000 .000,00 \text { dalam } \\
\text { setahun? }\end{array}$ & 41 & $42 \%$ & 56 & $57 \%$ & 97 & $100 \%$ \\
\hline PP6 & \begin{tabular}{|l|} 
Apa Bpak//bu/Saudara/i \\
selalu menyetorkan / \\
membayar PPh Pasal \\
25? \\
\end{tabular} & 66 & $68 \%$ & 31 & $31 \%$ & 97 & $100 \%$ \\
\hline PP7 & $\begin{array}{l}\text { Apakah } \\
\text { Bpak/lbu/Saudarais } \\
\text { pernah mendapatkan } \\
\text { surat teguran pajak? }\end{array}$ & 25 & $25 \%$ & 72 & $74 \%$ & 97 & $100 \%$ \\
\hline
\end{tabular}

Berdasarkan hasil kuesioner yang telah disebar dan yang berisikan 7 pertanyaan dapat disimpulkan bahwa kurangnya penerimaan pajak. Hal ini dapat dilihat dari jawaban responden tentang variabel Penerimaan Pajak.

Berdasarkan hasil penelitian yang telah dilakukan, bahwa benar pelaksanaan Self Assessment System dan kepatuhan Wajib Pajak Badan akan meningkatkan penerimaan pajak. Hal ini sesuai dengan hasil yang telah ditemukan yaitu :

Terkait pertanyaan Variabel Self Assessment System (SAS) dalam tabel IV-1 diatas, menekankan pada aktivitas self assessment system . Wajib Pajak terhadap seluruh SPT yang terkait baik massa maupun tahunan. Berikut ini adalah uraian dari hasil jawaban responden, yaitu:

\section{a. SAS 1}

Terkait pertanyaan SAS1, lebih banyak yang menjawab "tidak" dan jumlah yang 
Printed ISSN 2406-7415

e-ISSN 2655-9919

Jurnal Akuntansi \& Bisnis Krisnadwipayana

Vol. 6 No. 2 (Mei - Agustus) 2019

menjawab tidak adalah sebanyak 61 responden atau dengan jumlah persentase $62 \%$, hal ini dikarenakan para Wajib Pajak belum mendapat sosialisasi cara menghitung pajak dengan benar, meskipun pihak KPP sudah mengadakan sosialisasi melalui seminar, kelas pajak/klinik pajak, dan sosialisasi dengan mengunjungi Wajib Pajak, sebagaimana disajikan dalam tabel10 dibawah ini namun pada kenyataannya wajib pajak masih belum dapat mempraktekannya secara benar.

Tabel -10

Kegiatan Penyuluhan KPP Pratama Bekasi Barat Tahun 2015-2018

\begin{tabular}{|c|c|c|c|}
\hline Tahun & Jenis kegiatan & $\begin{array}{c}\text { Jumlah } \\
\text { Kegiatan }\end{array}$ & Jumlah Peserta \\
\hline 2015 & $\begin{array}{l}\text { Kelas pajak/klinik pajak, } \\
\text { Warkshop/bimbingan } \\
\text { langsung,sosialisasi dengan } \\
\text { mengunjungi WP. }\end{array}$ & 62 & 5.430 \\
\hline 2016 & $\begin{array}{l}\text { sosialisasi dengan } \\
\text { mengunjungi WP, Klinik } \\
\text { Pajak/kelas pajak, } \\
\text { Sarasehan/Tax Gathering, } \\
\text { Workshop/Bimbingan Teknis. }\end{array}$ & 72 & 6.867 \\
\hline 2017 & $\begin{array}{l}\text { Penyuluhan dengan Model } \\
\text { BDS, Kelas pajak/klinik } \\
\text { pajak, Sosialisasi dengan } \\
\text { mengunjungi WP. }\end{array}$ & 53 & 1.760 \\
\hline 2018 & $\begin{array}{l}\text { Kelas pajak/klinik pajak, } \\
\text { sosialisasi dengan } \\
\text { mengunjungi WP. }\end{array}$ & 19 & 713 \\
\hline
\end{tabular}

pertanyaan SAS 2, lebih banyak yang menjawab "tidak". Jumlah yang banyak menjawab tidak sebanyak 58 responden, atau dengan jumlah persentase $59 \%$. Artinya Wajib Pajak masih banyak yang melakukan penyampaian SPTnya melalui konsultan pajak.

\section{b. SAS 3}

Terkait pertanyaan SAS 3, lebih banyak yang menjawab "tidak" berjumlah 58 responden, atau dengan jumlah persentase $59 \%$. Hal ini dikarenakan masih banyak Wajib Pajak yang belum dapat melakukan pengisian sendiri atas SPT-nya dan masih melalui jasa konsultan, berikut ini adalah tarif konsultan pajak berdasarkan omzet WP Badan :

Tabel -11

Tabel Tarif Khusus Konsultan Pajak berdasarkan Omzetnya

\begin{tabular}{|c|c|c|}
\hline No & 0mzet & Tarif \\
\hline 1 & Pertushhaan beromzet 0(Nihil) & Rp 500.000 \\
\hline 2 & $\begin{array}{l}\text { Perusahaan beromzet Rp } 100 \\
\text { juta hingeg Rp } 1 \text { M pert thun. }\end{array}$ & Rp 1.500.000 \\
\hline 3 & $\begin{array}{l}\begin{array}{l}\text { Perusahaan beromzet Rp } 1 \mathrm{M} \\
\text { hingga Rp 4.8M per thun. }\end{array} \\
\end{array}$ & $\operatorname{Rp} 2.500 .000$ \\
\hline 4 & $\begin{array}{l}\text { Perusahaan beromzet Rp } 4.8 \mathrm{M} \\
\text { hingga Rp } 10 \text { M per tahun. } \\
\end{array}$ & Rp 4.500.000-Rp 5.000.000 \\
\hline 5 & Lebih dari Rp 10M. & Negotiable. \\
\hline
\end{tabular}

c. SAS 4

Terkait pertanyaan SAS 4, lebih banyak yang menjawab "tidak" berjumlah 71 responden, atau dengan jumlah persentase 73\%. Masih banyak Wajib Pajak yang belum melakukan pembayaran pajaknya dalam jangka waktu 1 (satu) bulan, padahal sudah dimudahkan untuk melakukan pembayaran pajak melalui fasilitas E-Billing, begitupun bank-bank sudah bekerjasama dengan DJP.

d. SAS 5

Terkait pernyataan SAS 5, sebanyak 63 responden mendominasi menjawab "tidak". Atau dengan jumlah persentase 64\%. Berarti masih banyak Wajib Pajak Badan yang tidak tahu cara menyampaikan dan mengisi SPT dengan benar dan lengkap, meskipun pihak KPP sudah mensosialisasikan melalui seminar, kelas pajak/klinik pajak, sosialisasi dengan mengunjungi WP, seperti di PT. Monysaga Prima, PT. Inti Panja Press Industri, dan PT. Sinar Sosro dan beberapa PT lainnya. Terkait pertanyaan Variabel Kepatuhan Wajib Pajak (KWP) sebagaimana tabel IV-6 diatas, SPT massa sudah melakukan E-filling, E-faktur, Berikut ini adalah jawaban responden, yaitu:

a. KWP 1

Terkait pertanyaan KWP 1, lebih banyak yang menjawab "tidak", dan berjumlah 72 responden atau dengan jumlah persentase sebanyak 74\%. Hal ini dikarenakan masih banyak Wajib Pajak yang belum menyetor dan melaporkan SPT masa dengan tepat waktu di setiap bulannya dan masih banyak yang belum mengerti cara pengisian SPT sesuai dengan sebagaimana mestinya. 
Printed ISSN 2406-7415

e-ISSN 2655-9919

Jurnal Akuntansi \& Bisnis Krisnadwipayana

Vol. 6 No. 2 (Mei - Agustus) 2019

b. KWP 2

Terkait pertanyaan KWP 2, lebih banyak yang menjawab "tidak", dan jumlah Wajib Pajak yang menjawab tidak sebanyak 55 responden atau dengan jumlah persentase sebanyak 56\%. Dapat disimpulkan bahwa masih banyak Wajib Pajak yang belum menyampaikan SPT tahunan dengan tepat waktu pada setiap tahunnya.

Tabel -12

Data Wajib Pajak Yang Terlambat Bayar

\begin{tabular}{|c|c|c|c|c|}
\hline N0 & Tahun & $\begin{array}{c}\text { Wajib Pajak } \\
\text { Terdaftar } \\
\text { (PKP \& NON } \\
\text { PKP) } \\
(\mathbf{1})\end{array}$ & $\begin{array}{c}\text { Wajib Pajak } \\
\text { Badan Wajib } \\
\text { SPT } \\
(\mathbf{2})\end{array}$ & $\begin{array}{c}\text { WP Badan } \\
\text { terdaftar wajib } \\
\text { SPT Terlambat } \\
\text { Bayar } \\
(\mathbf{3})=(\mathbf{1} \cdot \mathbf{2})\end{array}$ \\
\hline 1 & 2015 & 7.567 & 1.651 & 1.080 \\
\hline 2 & 2016 & 8.205 & 3.630 & 1.543 \\
\hline 3 & 2017 & 8.870 & 3.313 & 653 \\
\hline 4 & 2018 & 9.591 & 4.777 & 2.357 \\
\hline
\end{tabular}

c. KWP 3

Sesuai dengan pertanyaan KWP 3, sebanyak 68 responden atau dengan jumlah persentase sebanyak $70 \%$ menjawab "ya". Dimana wajib pajak belum benar dan patuh dalam pembayaran, pelaporan, dan pengisian SPT.

d. KWP 4

Terkait pertanyaan KWP 4, lebih banyak yang menjawab "tidak". Jumlah Wajib Pajak yang menjawab tidak sebanyak 51 responden atau sama dengan jumlah persentase sebesar 52\%. Dapat terlihat bahwa seharusnya sanksi atau denda pajak dapat membuat Wajib Pajak lebih memperhatikan ketetntuan-ketentuan yang berlaku dalam hal ketepatan jumlah bayar baik kurang maupun lebih, waktu pembayarannya, dan sesuai dengan tarif pajak-nya.

\section{c. KWP 5}

Pada pertanyaan KWP 5, lebih banyak responden yang menjawab "tidak" dengan jumlah 60 responden atau dengan persentase berjumlah $61 \%$. bahwa dapat dikatakan wajib pajak jarang sekali yang memiliki tunggakan pajak.
Terkait pertanyaan variabel Penerimaan Pajak (PP) sebagaimana disajikan dalam tabel-12 diatas, Berikut uraian dari jawaban responden dapat dilihat berikut ini:

a. PP 1

Pada pertanyaan PP 1, sebanyak 65 responden atau dengan jumlah presentase $67 \%$ yang menjawab "Ya". Sesuai dengan pertanyaan yang ada dapat disimpulkan bahwa Wajib Pajak sudah sadar akan membayar pajak sesuai tarif pajak yang sudah ditentukan.

b. PP 2

Dalam pertanyaan PP 2, responden dengan jumlah presentasenya $83 \%$ atau 81 responden menjawab "Ya". Bahwa Wajib Pajak sudah mengetahui secara jelas tentang tarif pajak Badan.

c. PP 3

Terkait dengan pertanyaan PP 3, lebih banyak responden menjawab "tidak" dengan jumlah presentasenya sebanyak $76 \%$ atau 74 responden. Data diatas menunjukkan bila Wajib Pajak merasa takut jika membayar pajak dengan tarif yang lebih tinggi apabila melaporkan income sesuai dengan apa adanya.

d. PP 4

Dari pertanyaan PP 4, sebanyak 85 responden menjawab "tidak" dengan jumlah presentase 87\%. Dikarenakan Wajib Pajak lebih mengutamakan dananya untuk kebutuhan lain, seperti dinas keluar kota dan pelunasanpelunasan hutang perusahaan.

e. PP 5

Terkait pertanyaan PP 5, lebih banyak yang menjawab "tidak" dengan jumlah presentase $57 \%$ atau 56 responden. Pada kenyataannya memang Wajib Pajak masih banyak yang tidak tahu cara penyusunan laporan keuangan yang sesuai dengan akuntansi apabila omset usahanya kurang atau lebih dari Rp. 4.800.000.000,00.-

f. PP 6

Terkait pertanyaan PP 6, dengan jumlah presentase $68 \%$ atau 66 responden yang menjawab "Ya". Hal ini menunjukkan bahwa Wajib Pajak sudah taat dalam melaporkan hutang pajaknya. 
Printed ISSN 2406-7415

e-ISSN 2655-9919

Jurnal Akuntansi \& Bisnis Krisnadwipayana

Vol. 6 No. 2 (Mei - Agustus) 2019

\section{g. $\quad$ PP 7}

Pada pertanyaan PP 7 lebih banyak yang menjawab "tidak" dengan persentase $74 \%$ atau 72 responden. Dapat diartikan bahwa banyaknya Wajib Pajak yang sudah tepat waktu dalam membayar pajak.

Efektifitas pelaksanaan Self Assessment System dan Tingkat kepatuhan Wajib Pajak Badan di KPP Pratama Bekasi Barat dapat dikatakan kurang patuh, hal ini dapat dilihat dari hasil penelitian yang telah dilakukan melalui penyebaran kuesioner kepada Wajib Pajak Badan yang terdaftar di KPP Pratama Bekasi Barat dan wawancara mendalam kepada beberapa responden bahwa masih banyak Wajib Pajak Badan yang kurang patuh terhadap pajak.

Berdasarkan hasil penelitian masih banyak Wajib Pajak Badan yang menganggap bahwa pelaporan pajak itu tidak terlalu penting untuk para Wajib Pajak, dikarenakan kesibukan para Wajib Pajak maka Wajib Pajak telat untuk memenuhi kewajiban perpajakannya, masih banyak juga Wajib Pajak yang tidak mengerti bagaimana cara pengisian SPT dengan baik, benar, dan lengkap, selain itu banyak juga Wajib Pajak Badan yang tidak mengetahui batas akhir pembayaran pajak maupun pelaporan dan penyampaian SPT, dan kepatuhan Wajib Pajak Badan di KPP Pratama Bekasi Barat juga bisa dilihat dari jumlah Wajib Pajak Badan wajib SPT yang setiap tahunnya menurun. Tentunya hal ini berpengaruh kepada target yang telah ditentukan oleh KPP Pratama Bekasi Barat dan menurunnya juga penerimaan pajak di KPP Pratama Bekasi Barat. Hal ini juga didukung oleh hasil wawancara yang telah dilakukan penulis kepada kepala Waskon III, yang menyatakan bahwa Wajib Pajak Badan yang terdaftar di KPP Pratama Bekasi Barat setiap tahunnya meningkat, tetapi Wajib Pajak yang wajib SPT, dan realisasi penyampaian SPT oleh Wajib pajak efektifpun setiap tahunnya menurun, dikarenakan kurangnya kepatuhan Wajib Pajak Badan dalam membayar, dan melaporkan pajaknya, tidak mengertinya Wajib Pajak Badan dalam pengisian SPT. Masih banyak juga Wajib Pajak yang tidak mengetahui kabar terkini tentang pajak sehinnga masih banyak Wajib Pajak yang tidak mengetahui batasan akhir pembayaran, penyampaian dan pelaporannya. Ada beberapa cara untuk meningkatkan penerimaan pajak yaitu dengan cara melakukan sosialisasi terhadap Wajib Pajak guna untuk meningkatkan kesadaran masyarakat terkait pentingnya membayar pajak, lebih mensosialisasikan tentang tarif pajak yang berlaku secara terus menerus, memberikan pelatihan-pelatihan tentang pengisian SPT dengan lengkap dan benar, mengadakan penyuluhan yang dilakukan DJP kepada Wajib Pajak seperti mempermudah Wajib Pajak untuk menyampaikan SPT melalui E-filling, E-faktur, E-billing atau bisa menyampaikan langsung ke bagian pelayanan, dan memberikan sanksi atau denda pajak kepada Wajib Pajak yang lalai agar mereka jera.

\section{KESIMPULAN DAN SARAN Kesimpulan}

Berdasarkan analisis data dan pembahasan diatas, maka kesimpulan penelitian ini dapat diuraikan sebagai berikut :

1. Tingkat pelaksanaan Self Assessment System dan Kepatuhan Wajib Pajak Badan di KPP Pratama Bekasi Barat bisa dikatakan kurang efektif dan kurang patuh, hal ini karena masih banyak Wajib Pajak Badan yang kurang peduli terhadap pajak. Ditunjukkan dari jumlah Wajib Pajak Badan efektif yang setiap tahunnya menurun (tabel I-2), selain itu juga masih banyak Wajib Pajak Badan yang tidak mengerti bagaimana cara pengisian SPT dengan baik, benar, lengkap dan tidak mengetahui tentang tarif pajak badan yang berlaku, masih banyak juga Wajib Pajak Badan yang tidak update tentang pajak sehingga masih banyak Wajib Pajak yang tidak mengetahui tentang batas akhir pembayaran, penyampaian, dan pelaporan pajaknya. Semua itu menandakan bahwa kepatuhan Wajib Pajak Badan di KPP Pratama Bekasi Barat menurun. Tentunya hal ini berpengaruh kepada penerimaan pajak di KPP Pratama Bekasi Barat.

2. Ada beberapa cara untuk meningkatkan penerimaan pajak yaitu dengan cara terus menerus melakukan sosialisasi terhadap Wajib Pajak guna meningkatkan kesadaran masyarakat terkait pentingnya membayar 
pajak, mensosialisasikan tentang Tarif Pajak Badan yang berlaku, memberikan pelatihanpelatihan tentang pengisian SPT dengan baik, benar, dan lengkap, mengadakan penyuluhan yang dilakukan DJP kepada Wajib Pajak seperti mempermudah Wajib Pajak untuk menyampaikan SPT melalui pos atau bisa menyampaikan langsung ke bagian pelayanan, dan memberikan sanksi atau denda pajak kepada Wajib Pajak yang lalai agar mereka jera.

\section{Saran}

Sebagai masukan dari hasil analisis dan pembahasan yang dilakukan pada bab sebelumnya, maka dapat diusulkan untuk Kantor Pelayanan Pajak Pratama Bekasi Barat seharusnya lebih mensosialisasikan kepada Wajib Pajak Badan secara efektif agar info yang disampaikan melalui website pajak.go.id dapat diperjelas sebagaimana operasionalnya/pelaksanaannya agar dapat diketahui kesiapan Wajib Pajak melaksanakan kewajibannya, guna meningkatkan kesadaran masyarakat terkait pentingnya membayar pajak, memberikan pelatihan-pelatihan tentang pengisian SPT, mengadakan penyuluhan yang dilakukan DJP kepada Wajib Pajak seperti mempermudah Wajib Pajak untuk menyampaikan SPT melalui E-filling, melakukan pembayaran melalui E-billing, melakukan pelaporan PPN via E-faktur atau bisa menyampaikan langsung ke bagian pelayanan, dan memberikan sanksi atau denda kepada Wajib Pajak yang lalai agar mereka jera.

\section{DAFTAR PUSTAKA}

H. Budi Prianto, 2017, Buku Pintar Pajak, Edisi

2, Jakarta : PT. Pratama Indomitra Konsultan

Teguh Hadi Wardoyo \& Amin Subiyakto, Taxation Pengantar Perpajakan Indonesia. Edisi 2017

Rochmat Soemitro, 2004, Asas dan Dasar Perpajakan 2, Bandung : PT. Repika Aditama
M. Zain, 2003, Manajemen Perpajakan, Jakarta : PT. Salemba Empat

Mardiasmo. 2011. Perpajakan. Edisi Revisi. Yogyakarta: Andi

Anastasia Diana \& Lilis Setiawati, 2015, Perpajakan Teori dan Peraturan Terkini, Yogyakarta : Andi

Hilarus Abut, 2012, Perpajakan, Jakarta : Diadit Media

Mardiasmo, 2016, Perpajakan, Edisi Terbaru 2016, Yogyakarta : Andi

Siti Kurnia Rahayu, 2012, Perpajakan Indonesia, Yogyakarta : Graha Ilmu

Siti Resmi, 2009, Perpajakan, Edisi Kelima, Jakarta : Salemba Empat

Siti Resmi, 2012, Perpajakan Teori dan Kasus, Jakarta : Salemba Empat

Soemarso, 2007, Perpajakan Pendekatan Komprehensif, Jakarta : Salemba Empat

Sony Devano \& Siti Kurnia, 2013, Perpajakan Konsep Teori dan Isu, Jakarta : Kencana

Sugiyono, 2007, Metode Penelitian Bisnis, Bandung : Alfabeta

Sugiyono, 20013, Metodologi Penelitian : Kuantitatif, Kualitatif dan R\&D,Bandung : Alfabeta Cetakan 13

Teguh \& Amin, Taxation Pengantar Perpajakan Indonesia, Jakarta : TaxSys

Thomas Sumarsan, 2013, Perpajakan Indonesia Edisi 3, Jakarta : PT. Indeks Permata Puri Media

Undang-undang Nomor 28 Tahun 2007 Tentang Perubahan Ketiga atas Undang-undang nomor 6 tahun 1983 tentang KetentuanUmum dan Tata Cara Perpajakan

Undang-undang Republik Indonesia Nomor 6 Tahun 1983 Tentang Ketentuan Umum dan Tata Cara Perpajakan

Waluyo, 2012, Perpajakan Indonesia, Jakarta : Salemba Empat

Waluyo, 2014, Perpajakan Empat, Edisi 11, Jakarta : Salemba Empat 
Printed ISSN 2406-7415

e-ISSN 2655-9919

Jurnal Akuntansi \& Bisnis Krisnadwipayana

Vol. 6 No. 2 (Mei - Agustus) 2019 